\title{
A Human Right to Science?: Precarious Labor and Basic Rights in Science and Bioprospecting
}

\section{Authors:}

Benjamin D. Neimark Lancaster University, Lancaster Environment Centre

A24 LEC 3 Library Ave, Lancaster, Lancashire, UK LA1 4YQ, email:

b.neimark@lancaster.ac.uk

Saskia Vermeylen Senior Lecturer and Chancellor's Fellow

University of Strathclyde, Strathclyde Centre for Environmental Law and Governance Glasgow , UK G1 1QE 
Accepted manuscript for the Annals of American Geographers, please do not cite without permission

\section{Abstract}

Does everyone have the right to benefit from science? If so, what shape should benefits take? This article exposes the inequalities involved in bioprospecting through a relatively neglected Human Right, the right to benefit from Science (HRS). Although underexplored in the literature, it is acknowledged that market-based conservation practices, such as bioprospecting, often rely on cheap “casual” labor. In contrast to critical discourses exposing the exploitation and misappropriation of indigenous people's cultural and self-determination rights in relation to bioprospecting (i.e., biopiracy), the exploitation of a low -skilled labor force for science has been little examined from a human rights perspective. Reliance on cheap labor is not just limited to those directly involved in creating local biodiversity inventories, but a whole set of other workers (cooks, porters, and logistical support staff), who contribute indirectly to the advancements of science, and whose contribution is barely acknowledged, let alone financially remunerated. As precarious workers it is difficult for laborers to use existing national and international labor laws to fight for recognition of their basic rights or easily to rely on biodiversity and environmental laws to negotiate recognition of their contribution to science. We explore to what extent the HRS can be used to encourage governments, civil-society, and companies to provide basic labor and social rights to science. This should be of keen interest to geographers, who for the most part have limited engagement in human rights law and has wider significance for those interested in exploitative labour and right violations in the emerging bio- and green economy.

Keywords: Human Rights, Conservation, Labor, Bioprospecting, Africa/Madagascar 
Accepted manuscript for the Annals of American Geographers, please do not cite without permission

\section{Introduction: On the Bioprospecting Trail}

In November 2005, the lead author was fortunate to observe a bioprospecting (drug discovery from nature) expedition with the largest U.S. federally funded projects - the International Cooperative Biodiversity Groups (ICBG). ${ }^{1}$ He was part of a group of Malagasy scientists, researchers, guides, and porters, traveling through a relatively unknown forest in Madagascar’s northernmost province of Antsiranana.

During the expedition, the lead botanist of the group, Jean, explained the purpose of a Geographic Positioning System (GPS) device to a group of porters hired from a nearby village. ${ }^{2}$ Jean remarked, “the device was given to me by a U.S. botanical repository. It is used to locate my exact position when I collect a plant, and when the plant is analyzed in a laboratory in the U.S. and found to have interesting medicinal qualities, I then can return to the spot and collect more.” Interested in exactly what the porters knew about bioprospecting, the lead author asked what they thought of people from the United States being so interested in plants growing in their backyard. One porter responded, “... what does a foreigner want with plants? Sapphire, gold, yes, but plants?” It was unsurprising that this was the first time they had seen a GPS device, since this remote area hosts relatively few outsiders, but why had these porters not heard of the team's reason for being there. Surely, they would at least be informed of the purpose of the trip-were these hired laborers not part of the bioprospecting mission?

The bioprospecting team was perceived by one of the porters as "whites who follow the path of previous prospectors.” Those hunting for minerals and other riches have a long and storied history in Madagascar. But this porter was now part of a new type of prospecting mission, one in which the correct biology and chemical "tinkering” might produce a new drug with value vastly more significant than minerals. Knowing that this was going to be a short-term 
Accepted manuscript for the Annals of American Geographers, please do not cite without permission

job, the porter wanted to benefit personally as much as he could, but was only able to negotiate a one-day wage of 5,000 Malagasy Ariary (MGA). ${ }^{3}$ In the opinion of one leading conservation practitioner, whose organization was part of the bioprospecting mission, “They [the porters] are happy to cash in their bioprospecting chips. It's like someone who gets paid to shovel in a gold rush.” This statement only adds to the multiple and complex layers of inequality that exist within bioprospecting and is reminiscent of Charles Zerner's notion that “the poor sell [their labor] cheap” (Zerner 2000, 9).

The porter, however, might also have been unaware of the highly polarized debate amongst academics and environmental activists surrounding the commodification and misappropriation of nature and rural and indigenous peoples' knowledge systems for bioprospecting (known as biopiracy) (Shiva 1997; Hayden 2003; Parry 2004; Neimark 2012). This long-standing debate has only intensified since the launch of a host of new marketconservation "bioeconomy” and "green economy” initiatives by large multilateral development organizations, such as the United Nations Environment Programme (UNEP). The bioeconomy is generally defined as the "production of renewable biological resources and the conversion of these resources and waste streams into value-added products, such as food, feed, bio-based natural products and bioenergy” (EC 2009); the green economy seeks to capitalize on the products and services (natural capital) nature provides for biodiversity offsetting and other carbon-trading schemes (i.e., Reducing Emissions from Deforestation and Forest Degradation [REDD+]). In theory, the discovery of value-added, bio-based products and services will help address global environmental challenges such as food security, biodiversity loss, and climate change, whilst delivering inclusive socio-economic development. Yet for some time, studies have shown that the acceleration of market conservation has not only increased the commercial value of biodiversity, but also potentially risked the social integrity of indigenous and local communities, sometimes leading to a loss 
Accepted manuscript for the Annals of American Geographers, please do not cite without permission of cultural diversity and overexploitation (Vermeylen, Martin, and Clift, 2008; Neimark 2010).

In recent years, geographers and other scholars have focused their critique on the discourse and material nature of market conservation and expanding power of global environmental governance (Brockington and Duffy 2009; Fletcher 2010; Büscher et al. 2012; Roth and Dressler 2012), effects on local communities (McAfee and Shapiro 2010; Cavanagh and Benjaminsen 2015) and the emergence of labor exploitation by multinationals and development agencies (Sodikoff 2009; Neimark 2012). Madagascar, especially, has been a key point of departure for many critical scholars observing the disproportionate burdens of conservation interventions on the rural poor (Walsh 2012; Keller 2015). Less explored in the literature on the bioeconomy/green economy in general, and bioprospecting specifically, is exploitation of a precarious manual or "casual” scientific labor force. This silence is positioned within an increased awareness that the monitoring and valuation of biodiversitya process vital to market conservation—by professional scientists is expensive. Hence the scientific conservation community actively recommends that projects make more use of a locally based, low-skilled workforce (Janzen 2004; Danielsen, Burgess, and Balmford, 2005). Alarmingly, most of the studies recommending the use of a local workforce ignore the issue of labor exploitation. At best they pay lip service to the idea that rangers, amateur naturalists, and local resource users trained as plant collectors (parataxonomists) can form the backbone of biodiversity projects and should be remunerated for their efforts. When a "country bumpkin [is] formed into a parataxonomist ... they [become] employees producing and paying their bills” (Janzen 2004: 184). Yet there remain many unanswered questions about the role of labor and the recognition of workers in international bio- and green economy programs, particularly since success for conservation organizations often hinges on sharing conservation benefits and inclusion in the scientific process. 
Accepted manuscript for the Annals of American Geographers, please do not cite without permission

Does everyone have the right to benefit from science? If so, what shape should benefits take and how should they be shared? Should the burdens of science, including adoption of technologies and policies from discoveries, also be shared? Answers to such questions have been at the heart of renewed debates concerning the often neglected Human Right to benefit from Science (HRS). In an interview, Farida Shaheed, UN Special Rapporteur for the Committee on Economic, Social and Cultural Rights, noted that the HRS is in essence about "the right to self-determination and participation.” She went on to say:

Access to science must include participation in the whole scientific process-it's not just the end product. You have the scientific process, then the knowledge that's created, then the applications. All of those things make up the right to science. ${ }^{4}$

Science is rarely considered as a substantive human right, but the HRS is explicitly mentioned in Article 27(1) of the Universal Declaration of Human Rights (UDHR) and Article 15(1b) in the International Covenant on Economic, Social and Cultural Rights (ICESCR). ${ }^{5}$

Our original contribution, which we argue differs from mainstream debates about bioprospecting as biopiracy or theft of knowledge and nature, is twofold. First, we seek a wider interpretation of the HRS which defines "sharing as participation," and interpret Articles 27 and 15 of the UDHR and ICESCR, respectively, in the broad sense as "actively participating in scientific progress.” In doing so, we also link the articles (27 and 15) to Article 6 of the ICESCR which highlights the, "right to work" and "sustainable access to decent work that meets the needs and welfare of its livelihoods.” In a similar vein to what Olivier De Schutter (2011) has done to link the right of everyone to enjoy the benefits of scientific progress with the right to food, we hold that Articles 27 and 15 must be linked to Article 6 to reach its full potential to protect local communities from the harm of scientific 
Accepted manuscript for the Annals of American Geographers, please do not cite without permission

progress, and most importantly recognize workers associated with bioprospecting who are contributing indirectly to the development of new products. ${ }^{5}$ It is precisely the "fuzziness" of their scientific contribution which makes them vulnerable, falling through the cracks separating biodiversity laws and regulations and international labor rights.

Our second contribution is to draw out these vital linkages through a detailed empirical case study of the ICBG bioprospecting project in Madagascar. Madagascar is an ideal prism for viewing the integration of the HRS, labor, and the bioeconomy. Rich in endemic biodiversity, it has for years been labeled a bioprospecting "hotspot," and a gateway for new marketconservation programs based on drug discovery. Moreover, projects such as ICBG seek an enhanced role for the private sector and civil society-from conservation non-governmental organizations (NGOs) to research institutions_-in the (re)regulation of nature through forms of commodification of bio-based products and services. Ideally, monetary benefits from the discovery and commercialization of new natural products would provide the impetus, and more importantly the critical funding, for the conservation of the island's unique biodiversity. $^{7}$

We highlight the role and responsibility of non-state or "third party” groups (e.g., companies, universities, and private research institutions and environmental NGOs) who are now being called upon to ensure that human rights to science and other livelihood and sustainable development needs (e.g., access to food and water) are recognized and addressed (Bebbington, Hickey, and Mitlin 2008; Hickey and Mitlin 2009). In doing so, this study seeks to better understand the integration of conservation science, labor, and human rights, and is, therefore, highly relevant for those questioning value creation and development around new carbon trading and mining offsetting schemes, and other green economy platforms (e.g., ecotourism). Our use of the HRS should also be of keen interest to geographers and other 
Accepted manuscript for the Annals of American Geographers, please do not cite without permission

social scientists, who for the most part have limited engagement in human rights law and its links to market conservation and sustainable development.

\section{Human Rights to Benefit from Science and the Precarious Conservation}

\section{Worker}

It is highly unusual to think about science as a substantial human right, and so the HRS has become particularly obscure and neglected. Some applications of science, such as chemical weapons development, are outright infringements of a human rights approach; others, such as using science as a way of improving development—as stipulated by the Task Force on Science, Technology, and Innovation within the context of the UN-may be more difficult to link directly to substantive human rights. Despite the obvious connection between science and improvements in healthcare, food security, and a clean and safe environment, there is a reluctance to attribute the improvement in human welfare due to scientific developments as a human right in and of itself (Chapman, 2009). Yet Article 27 of the UDHR has two provisions related to science:

- Everyone has the right freely to participate in the cultural life of the community, to enjoy the arts, and to share in scientific advancement and its benefits.

- Everyone has the right to the protection of their moral and material interests resulting from any scientific, literary, or artistic production of which he is the author.

Furthermore, Article 15(1b) of the ICESCR recognizes "the right of everyone to enjoy the benefits of scientific progress and its applications.” Within the context of this article we are particularly interested in interpreting the meaning of this wording. There remains ambiguity as to whether the right must be interpreted as meaning to benefit from the dissemination of 
Accepted manuscript for the Annals of American Geographers, please do not cite without permission

the fruits of scientific progress or to a more substantial and fundamental benefit to participate in its development as well. However, arguably it requires both interpretations:

Like all human rights, the human right to the benefits of scientific progress and its applications imposes a different set of obligations on states than promoting or using science for other purposes, even noteworthy goals ... It also necessitates that the process of doing scientific research and the development of applications from that science be consistent with fundamental human rights principles (Chapman 2009: 11).

The emphasis that Chapman gives to the process of scientific research and how this should not infringe upon other human rights principles is especially pertinent within the context of labor relationships between scientists and an unskilled workforce in the biodiversity sector. In other words, the HRS is not only an instrument that can be used to hold states and third parties accountable for the wider dissemination of scientific research beyond those who directly contributed to the scientific advancements, but also a mechanism to instill upon the scientific community the requirement to develop better employment regulations when working with or using unskilled labor.

In her study of forest conservation projects in Madagascar, Genese Sodikoff (2009: 445) argues that silencing of the labor debate concerning low-skilled workers is not "for lack of political sympathy with local labor but, rather, relates to the way that conservation has been imagined as an antithesis to production.” Yet conservation science has a long history of subjugating local practices and has become part of the “civilizing mission” of European empires (Anderson and Grove 1987). Also relevant is the articulation by Jasanoff $(2006,277)$ of the way scientific knowledge in the biotechnology industries influences global governance of genetically modified seeds. Yet, even more recently, geobotanical and geospatial sciences have been highlighted by geographers for the power embedded in scientific data not only to 
Accepted manuscript for the Annals of American Geographers, please do not cite without permission

quell and control resistance to biopiracy (Wainwright 2012), but also to identify and commercialize previously uncommodified nature for "sustainable" outcomes in the green economy (Fairhead, Leach, and Scones 2012; Neimark and Wilson 2015). Nevertheless, most debates surrounding the integration of market conservation and science still coalesce around ethical "codes of conduct” of research scientists built within current biodiversity treaties, such as the Convention on Biological Diversity (CBD) and Nagoya Protocol on Access to Genetic Resources and the Fair and Equitable Sharing of Benefits.

Under the auspices of the Science and Human Rights Coalition, there is increased awareness that scientists have a wider responsibility to society than just accountability to fellow researchers. ${ }^{8}$ Unfortunately the exact nature of that responsibility remains vague and highly contestable amongst scientists themselves; for instance, scientists' social responsibility (Wyndham et al. 2015) includes no mention of fair payment and social security for a lowskilled workforce, or rights to scientific education or technology transfer for marginalized groups. It is clear, however, that it is no longer just up to the state to fulfill such obligations. So how are third parties engaging in labour contracts, and what duties to they have towards their labour force? As Chapman $(2009,25)$ clearly indicates, the private sector and civil society have an increasingly important role to play in HRS obligations. She gives a full list of functions that third parties can deliver, some particularly poignant within the context of bioprospecting. In summary:

- Prioritize the development of science and potential societal benefits to poor and disadvantaged groups;

- Evaluate discoveries and technologies developed elsewhere for the benefit of local populations; 
Accepted manuscript for the Annals of American Geographers, please do not cite without permission

- Develop laws, institutions, and policies to monitor and regulate science, including potential harmful effects, and inform the public of these measures;

- Provide a science education program;

- Undertake ongoing public outreach and education, and allow the public to participate in decision making;

- Enable public engagement in decision making about science;

- Provide distribution systems through which the benefits can reach those who have hitherto been disadvantaged;

- Develop a national plan of action and monitoring strategy to rectify inadequacies. ${ }^{8}$

We find it surprising that non-state actors are not usually held accountable under the HRS, especially since their obligations are outlined alongside other key statutes such as the InterAmerican Commission on Human Rights, 1993 Vienna World Conference on Human Rights, and Maastricht Principles on Extraterritorial Obligations of States in the Area of Economic, Social and Cultural Rights (ETO) (De Schutter et al. 2012). ${ }^{10}$ Yet, rather than quelling the matter, these agreements have provided fertile ground for debate about the role of states, and the increasing involvement of non-state groups, to fulfill their legal and moral obligations to the proclaimed HRS (Shaver 2010). For example, according to the UDHR, governments are not necessarily responsible for infractions that might take place by third party actors such as private companies and institutions; nevertheless, “[s]tates may breach their international human rights law obligations where such abuse can be attributed to them, or where they fail to take appropriate steps to prevent, investigate, punish and redress private actors’ abuse” (UDHR, 2011, 4). Given that the role and responsibility to ensure human rights do not reside 
Accepted manuscript for the Annals of American Geographers, please do not cite without permission

with states alone, but with other industry and civil society actors, it is reasonable to question the role of these other actors in ensuring equitable sharing of benefits and burdens of integrated science, conservation, and development projects such as bioprospecting in ICBG.

\section{Combining the HRS and Labor Law for Unskilled Workers in the}

\section{Conservation Sector}

The growing unskilled labor force embedded in conservation and bioprospecting projects is a sign of the growing trend towards precarious, temporary, and informal forms of work. Unskilled laborers in the "conservation sector” are part of an "unprotected work" category comprising a "precarious, or marginal type of economic activity, directly or indirectly subject to decisions of powerful actors in which workers have limited input” (Bernards, 2015, 13). Informal working arrangements, temporary labor migration, and subsistence production are widespread in the rural developing world so at first sight exploitation of unskilled labor in the biodiversity sector appears unexceptional. However, as the literature suggests, there is a new sense of urgency concerning unskilled labor relations, particularly in the global south. First, subsistence farmers are being pushed into wage labor through forced displacement and evictions due to new market conservation under green economy and bioeconomy platforms (Fairhead, Leach, and Scones 2012) and large-scale land acquisitions for biofuel and export crops (Li 2011). Second, public sector workers are finding their relatively "protected” position eroded through retrenchment of the state and geographical displacement of traditional employment sectors. Finally, and the most poignant change for the biodiversity sector, contemporary forms of unprotected work take place against more entrenched power relationships whereby workers are incorporated into transnational relations of scientific production subject to the power of socially and geographically distant core actors (NGOs and multinationals) (Bernards 2015, 13). 
Accepted manuscript for the Annals of American Geographers, please do not cite without permission

We recognize that the human rights agenda is neither a silver bullet for the protection of workers’ rights, nor devoid of its own inherent controversies (Kumar 2014). For some, human rights are perceived as a powerful legal discourse assuring justice, emancipation, and progress (e.g., Donnelly 2003) and linked with the intellectual and political tradition of liberalism which strives for the protection of the individual against state violence. However, for others, these same rights are observed as not delivering intended outcomes (Koskenniemi 2005). ${ }^{11}$ Furthermore, the historical legacies of human rights suggest linkages to the moral status of seventeenth century natural rights claims and law's positivistic nature, both criticized as disrespectful and oppressive of non-Western values (Buss and Manji 2005).

Despite these criticisms, "human rights have become the sine qua non of a rights discourse," and within the context of exploring the emancipatory scope of international law, human rights have been perceived by some as more impactful than labor laws (Kumar 2014, 128). Nonetheless, opinions vary as to how labor laws should at the very least employ, but ideally merge with, human rights (Gross 2003). The merits of these different approaches notwithstanding, the history of labor and human rights have followed distinctive, often separate, trajectories (Kumar 2014). Nevertheless, we argue that these are not mutually exclusive. From a legal positivistic approach, many rights treaties already recognize labor rights as a human right (Mantouvalou 2012). Article 4 of the UDHR prohibits slavery, and Article 23 stipulates that everyone has the right to work in a freely chosen job and should receive sufficient remuneration to guarantee a dignified life for themselves and their family. Also the International Labour Organization (ILO) has in the past endorsed a list of labor rights as specifically germane to human rights (e.g., in 1998 it adopted the Declaration of Fundamental Principles and Rights at Work). ${ }^{12}$ While critics argue that these treaties often fail to live up to their stated goals, from an instrumental point of view there is significant evidence that courts, trade unions, and international civil society treat labor rights as a human 
Accepted manuscript for the Annals of American Geographers, please do not cite without permission

right. In particular, the European Court for Human Rights has recently been very active and supportive to workers' claims and has used principles of the European Convention of Human Rights in employment; therefore, from a normative viewpoint, there are persuasive moral reasons to treat certain labor rights as human rights on the basis that they are compelling, stringent, universal, and timeless entitlements (Mantouvalou 2012). ${ }^{13}$

The shortcomings of international biodiversity agreements and labor laws, as well as organizations, to protect marginal Malagasy conservation workers have been well documented (Sodikoff 2007, 2009; Neimark 2012). ${ }^{14}$ For example, Sodikoff (2012) argues that “subaltern labor” provided by low-wage conservation workers in Madagascar has not only protected and monitored the forest, but built paths, guided tourists, monitored tree growth and rainfall, carried equipment, and identified species. This is built on a long history of colonial forest service, where French “experts” outranked “indigenous” workers, and evolved out of the work of Malagasy carriers who served as porters to natural historians and collectors. Sodikoff's research is instrumental in exposing the paradox whereby workers' underpaid labor keeps them dependent on the practices of shifting cultivation, ultimately undermining the NGO's forest conservation goals. Even more relevant is her description of Malagasy workers of a prominent conservation NGO successfully forming a union and holding a "first of its kind” strike for better pay and labor rights (2009, 444). Subsequently, the organizers of the strike were laid off when the NGO's management of the protected area was transferred to the national park service, and while the strike was recognized by the NGO, the union was not. We highlight this case not to undermine the immense importance of organized labor and the significant contributions it has played in protecting workers’ rights, but rather to highlight the precariousness of conservation workers’ employment, necessitating a more integrated framework fusing human and labor rights. 
Accepted manuscript for the Annals of American Geographers, please do not cite without permission

Our second point is that these workers need recognition by both state and non-state entities of their contribution to the scientific project. Currently, in conservation programs, only certain processes of labor and knowledge are being recognized as valuable contributors to new products and scientific developments. In her study of biodiversity conservation scientists in Indonesia, Lowe also finds that a "post-colonial condition” overshadows and undervalues the work of Tongan locals who "struggle for recognition within transnational scientific domains" $(2006,13)$. While we argue that this co-production of nature and scientific knowledge has for some time been recognized by critical scholars and activists as an assemblage of institutions, identity, and social and political relations, rarely is unskilled scientific labor recognized as a critical factor in any benefit-sharing agreements. Moreover, NGOs and the scientific research community (e.g, research institutes and universities) are not usually included within international labor standards more focused on industrial policy, so recognition of unskilled scientific labor is affected by shortfalls in both labor law and labor organizations.

Embracing a pragmatist approach towards human rights, we follow the idea of Ignatieff (2001) that it may be more important to concentrate on the rights themselves than to focus on the historical and philosophical foundations of the principles: “... [T]he pragmatic approach to human rights stresses the role of rights in practical politics, law and interpersonal relations rather than the metaphysical foundations for a belief in rights” (Hiskes 2005, 1362).

Following Dewey and other pragmatists, in this context we believe that human rights have a role to play in looking for a “participatory democratic deliberation” (Hiskes 2005, 1362) and that they are needed to tackle the emergent reality that low-skilled workers are being exploited in bioprospecting contracts.

In the following two sections, we connect the pragmatist approach to the HRS with bioprospecting observations and narratives from the field. First we outline the history and 
Accepted manuscript for the Annals of American Geographers, please do not cite without permission

development of ICBG, then describe local Malagasy perceptions of the bioprospecting project. We show how little Malagasy understand of the drug discovery process and their precarious position as laborers in the commodity chain.

\section{The International Cooperative Biodiversity Groups (ICBG)-Madagascar}

The ICBG is composed of private and public international organizations, research institutions, and companies involved in a large-scale collaborative effort to discover novel pharmaceutical and agro-industrial products. Specifically, ICBG-Madagascar is a bioprospecting project which originated from the Biodiversity Utilization in Suriname Project (1993-1997), itself one of five initial projects contracted by ICBG in 1993. After the first funding cycle, the team then submitted a proposal for the second round of ICBG in conjunction with some of the larger organizations involved in Suriname who also had operations in Madagascar. ${ }^{15}$ Subsequently, the team was granted a second five-year round of funding, and expanded to Madagascar. This stage of the project, designated Phase I (19972003) in Madagascar, was designed around plant collections within the Zahamena National Park, in the eastern forests of the Toamasina (Tamatave). A third round of funding was then awarded (2003-2008), this time for work solely in Madagascar, consisting of plant and marine collections in Antsiranana (Phase II). The last and final round of funding (2007-2013) (Phase III) included microbial collections within five centrally located conservation sites comanaged by the lead ICBG botanical collection institution, Missouri Botanical Garden (MBG). ${ }^{16}$ It was this last round which instituted the systematic collection of soil microbes (Robinson 2014), mirroring growing scientific interest in microorganisms worldwide.

In order to follow the "spirit" of benefit-sharing found in the CBD, ICBG has supported economic conservation interventions in rural collection areas. These programs offer economic incentives to the central Malagasy government and communes rurales (main, lower 
Accepted manuscript for the Annals of American Geographers, please do not cite without permission

level rural municipal administrative unit) and the fokontany (the smallest admin level in the communes) to conduct rural-level micro-development projects or "microprojects". The term “upfront compensation” is commonly used to describe these payments, with funds provided before or during collection, prior to any other potential monetary returns such as royalties or milestone payments received after any discoveries. For ICBG, the logic behind the compensation scheme is straightforward: drug discovery is complex, taking a great deal of time (it is estimated to take 10-15 years to bring a drug to market). This upfront payment accordingly provides an example of process benefits that may be gained from protecting local biodiversity. Moreover, the project holds that by providing rural Malagasy with some economic alternatives through income-generating activities, they will begin to reduce charcoal production, pasture burning, and other "unsustainable” livelihood practices such as forest burning for upland rice cultivation (known as tavy), and begin buying into long-term conservation stewardship. ${ }^{17}$

However, the way that bioprospecting is conducted with small collection teams hiring shortterm porters and guides raises important questions regarding who is able to capture the majority of the benefits and just what the burdens of participation are. These questions were posed to rural residents living in collection areas to provide a better understanding of Malagasy perceptions of project benefits and burdens, and rural residents’ sense of distributive mechanisms within ICBG.

\section{Participation in ICBG}

Once the bioprospecting team obtains collecting permits from the Malagasy government, there is no other legal obligation for them to respond to demands from any local authorities or inhabitants before entering a forested area. ${ }^{18}$ However; it is ICBG policy to arrange a “courtesy” visit with rural Malagasy authorities before collection. This short meeting 
Accepted manuscript for the Annals of American Geographers, please do not cite without permission

(kabary) between the project and the president of the fokontany greatly benefits the researchers. ${ }^{19}$ It is an opportunity to explain the researchers’ objectives and needs, and begin the process of selecting workers, including fifteen to twenty men and women chosen by the village head to work as guides, cooks, and porters. Generally, these posts are delegated to family members and those close to either customary or political authority selected to represent the village. There is specific gender selectivity, with women sometimes chosen as cooks, but not generally picked for other tasks. The meeting usually provides the researchers unlimited access to intact forests near the village during collection and guarantees their safety throughout their stay.

Payment is given at the ICBG rate of 5,000 MGA per day. Due to the somewhat easy access to many of the areas in Antsiranana, porters usually work for two days (one-day drop off and one-day return). Cooks and guides stay for the duration of the trip, and maybe for multiple trips, depending on the next location. The porters each carry 25-30 kg of materials and food to and from the site. The site is usually proposed by the hired guide in the area, with criteria including water availability and a central location allowing the guide to maintain access and personal communication with the village, and in return the village to keep an eye on researchers.

Being hired as a worker is seen by many in the village as a favor passed down through the village administration. Although legally the researchers may enter the forest, their collecting activities could be disrupted if they do not hire from the area-in the end, hiring "local” is vital for success. As Lanto, a porter hired by the team, indicated:

Yes, they are allowed to go into the forest, and we can’t do anything to stop them. All we need is money and we won't do anything. We don't know much about what they do, but if they [researchers] give us something for our pockets [money], we won’t bother them. 
Accepted manuscript for the Annals of American Geographers, please do not cite without permission

However, not everyone was in line with how benefits were exchanged, as observed by Henri, a rural resident:

If they [ICBG] tell us that they get new drugs from the plants, and not hide it, maybe there will be a benefit for people in the village. Still, we didn't know why they had gone into the forest, and it was only after they came back that we found out. In the end, we didn’t know if they had their collecting permits or not.

This confusion as to just what the project was about leads to the question: how are rural Malagasy to learn about the benefits of bioprospecting if even those involved in the project are left without any significant knowledge of the project's mission? And beyond a few days of employment, how else are Malagasy participating in ICBG? For example, what are they learning and what is the interaction? And how much knowledge do they pass on to others? Then in terms of employment? And are there different rates depending on the job or their gender?

Whose Water Trough is This?

Prior to any work in the areas, ICBG information meetings were held within the two rural communes of Ramena and Mahavanona and a larger meeting was held in Antsiranana. The purpose was to explain the application procedure to apply for rural-level microprojects funded by ICBG and how the vetting process for selection would proceed. Applications were to be written by the commune head and sent to a screening committee composed of the Malagasy representatives of the three leading organizations of the ICBG—-the Malagasy National Institute for Applied Pharmacological Research (CNARP), MBG, and Conservation International (CI). By the end of the application process, fifteen small- and medium-range projects were selected in the three different communes: Nosy Be (marine site), and Ramena and Mahavanona (terrestrial sites) (see Table 1). 
Accepted manuscript for the Annals of American Geographers, please do not cite without permission

\section{TABLE 1 HERE}

For many scientists involved in the project, the benefits returned to the villages, either in the form of labor payments or the microprojects themselves, were viewed favorably. For example, the virtues of the microprojects are mentioned repeatedly by ICBG representatives as “...a method of giving something back to the source country and especially the local community.” The permanent representative of MBG, for example, commented on the completion of a Phase I microproject:

There was the construction of a bridge and granary. I was there during the inauguration [of the bridge]. They were happy to see their work accomplished. The real advantage of the bridge allowed the villagers to get to the hospital easier.

But how do the rural inhabitants view the microprojects? For some, such as the president of Varindirina, they seemed like an equivalent exchange for their resources:

I think it is equal. They came here only once. They spent one week and gave us [Varindirina] 14,000,000 $\operatorname{Ar}[\approx$ U.S. \$6,900]. So, I think it is equal. Maybe they got more compared to what they took but whatever we get is already fine for us.

More generally, within the three villages surveyed, residents' accounts of the microprojects were mixed and participation in the microproject and implementation were largely limited to a few individuals in each. And even though all three villages had microprojects that were actively or previously constructed, most residents had little or no knowledge that they were even occurring, much less that they were linked to ICBG.

As shown earlier with knowledge of the ICBG, there seemed to be "collective ignorance" among rural inhabitants about the microprojects, suggesting that project choices may have had no rural-level input at all. For those who did know anything about the project, the survey 
Accepted manuscript for the Annals of American Geographers, please do not cite without permission

seemed to show that knowledge was only diffused to those who lived close to the project sites, or who were either direct relatives of the president or worked with him in some capacity (e.g., vice-president of fokontany, school teacher). An example of villagers' description of benefits was noted by the president's brother:

The president reported to us during a meeting that we had ... the project about the dam is related to the fact that MBG came here [the benefit we got from them]; however the microproject about keeping chickens or ducks is to make people stop making charcoal which destroys the forest.

In many interviews, villagers said they felt the microprojects did not represent what they wanted. For example, since a very few actually owned zebus (the local breed of cattle), a watering trough was not suitable. When asked, the president of the fokontany of one of the villages why many of his residents felt disappointed in what ICBG delivered, he said:

It was a bit difficult, because there was no participation of people in the village. If we want to carry out a successful microproject, people should participate. The money is already there, but people don't want to participate. In Sabatinava, for example, the water place has already been dug, but people don’t want to work on it. And I don’t know why. What I think happened is that what commune gave us is not what people really want. They want to raise chickens or do something that people can get a direct benefit. People don't want a well or a watering hole.

When asked further why a watering trough was selected, he expressed the project's urgency “...in getting a project done, rather than what people really wanted.” In another interview a village president said: 
Accepted manuscript for the Annals of American Geographers, please do not cite without permission

They [ICBG] said they asked them [the residents], but people didn’t really understand the process. So ICBG planned the project, but I think it was only done on table [ICBG didn't go to the village to ask people’s opinion]. They just did it. The commune didn’t protest because they knew it was something urgent to get done.

Questions of "who benefits” from a project might better be rephrased as, who has the ability to participate and what does participation mean in terms of trade-offs and costs to the individual or group? In fact, beyond the daily wage to porters, guides, and cooks, many felt that overall neither they personally nor the village benefited from the project, and many were eager to highlight how some benefited more than others. For example, Bako, a farmer in Varindirina, if she had received any direct benefit from the project, she said:

Only the president received benefit from these researchers because he went with them. He has also taken some people from the village with him, but they are the only ones who get money. They gave him money and gifts. Moreover, he didn’t report to his people what they did there. Even people in the village don't know what they are doing there.

Since the president was cited by many respondents as a major, and sometimes only, recipient of benefits, the respondents also questioned the role of the "community” commonly featured in bioprospecting projects. In reality, the rural residents we spoke with represented groups of differentiated individuals whose benefits from bioprospecting varied from a one-time cash payout to nothing at all, and whose participation consisted of a couple of days' work for a few workers at most. One local observer summed up the situation by claiming that the bioprospectors were just following a long line of other vazáha (foreigners) who came to their forests and extracted “their” resources. This was reflected in the following reaction by Bako: 
Accepted manuscript for the Annals of American Geographers, please do not cite without permission

They take everything they want, for example [precious] stones ... but they analyze everything they get. What is written in their permit is like a title that they are going to collect plants, but in fact they collect something else after ... [t]hey can go everywhere with their permit ... these foreigners [researchers] come here because there are lots of things in the forest ... there are gold and sapphires ... there are treasures there.

In Malagasy, use of the term misy valeur be ao ("there are treasures there") in this context is particularly significant, because it reflects knowledge of the researchers' mission to extract resources that may be both "unique” and “quite valuable.” It also indicates that rural residents are aware that their forests contain among the richest biodiversity in the world and that it is important to control access so that they can benefit from anything extracted. ${ }^{20}$ As Mamy, a rural resident in the village, reflected:

The microproject is not compensation given by the researchers for collecting plants; it is to get the people out of the forest. We haven't seen the compensation yet [from the researchers] ... and it will probably never come. The important people will keep it. That's why I said that it is better that we take over the management of the forest. ${ }^{21}$ Similar to other peasant economies, rural Malagasy depend on the forest for a number of livelihood resources. Unlike the southern and eastern regions of Madagascar where forests are used for tavy or upland shifting-cultivation agriculture, forests in Antsiranana provide multiple economic and social benefits including timber for construction, fodder for livestock, fuelwood, charcoal, medicinal plants, and fibers. Furthermore, for many rural Malagasy, forests also hold sacred cultural significance. However, the many ways Malagasy use the forest are not factored into the design of microprojects, rather they are meant to get Malagasy 
Accepted manuscript for the Annals of American Geographers, please do not cite without permission

"out of the forest” altogether, simply adding to the considerable burdens borne by a vulnerable group. ${ }^{22}$

Benefits on the Cheap: Milestone Payments and Royalties

Of the different types of benefits that may arise from a bioprospecting project, royalties and milestone payments are the monetary benefits that have been most analyzed, but least realized. In a bioprospecting project, milestone payments are usually generated when significant discoveries are made at successive stages of the research, whereas royalties only come following full commercialization of a natural product. There have only been a few reported cases where cash payments in the form of royalties were shared by rural actors incorporated into a bioprospecting project.

For those involved in the ICBG in Madagascar, if there was a royalty agreement set in place, the rural inhabitants were the last to know. In fact, very few rural Malagasy understood why they might even be entitled to any royalty rights; they similarly lacked knowledge as to how they would be compensated if these payments were to arise. As expressed by two rural residents in Sabatinava:

Andre: I think it is a good project because of the common benefit. If they will get new drugs from what they have found in the forest, everyone in Madagascar will all benefit from the drugs. And we expect a lot in return.

Interviewer: So, as far as you're concerned, have you received any benefits from those researchers? Money or any kind of help?

Lano: We haven't received any benefit. They just collected the plants, put them in a big bag and they were gone. 
Accepted manuscript for the Annals of American Geographers, please do not cite without permission

Interviewer: So, you haven't received anything?

Lano: Nothing! However, they said that one day, they may be able to make something

[drugs] from the plants and that can be our benefit. At least, that's what they said.

Within the three sites investigated, we could not find any rural residents in the surrounding Montagne des Français area who had had ICBG royalty payments explained to them in detail. The only person with any significant knowledge of a monetary benefit scheme was Rokoto, the president of Ambatofaroa:

Rakoto: In my opinion, I think it is an exchange because they collected plants that they would turn into medicine, and then would sell it to get money. Part of the money [they would get when the medicine is made], but I don't know how many percent will be for the villages where they collected the plants. That's how they explained it to me.

Interviewer: Did they tell you what percent?

Rakoto: They didn't tell us the percent of the money that would be for the village. They just said what they gave us is a benefit from the plants they collected, and they [ICBG] would manage the money.

Recent work by Keller (2015) highlights the confusion Malagasy feel when confronted by the layers of development agencies and other research actors surrounding the Masoloa protected area. In her chapter "Who Are They,” she skillfully describes a situation which plays out repeatedly in Madagascar, where multiple state, private sector, and civil society actors visit protected areas for a variety of different and sometimes contradictory reasons, often just to make speeches and hold ceremonies. She describes how, in one instance, a Swiss bioprospecting team from the fragrance and flavor giant Givaudan, floated a hot-air balloon over the forest canopy to collect flowers for perfumes. Locals, who worked for the teams, 
Accepted manuscript for the Annals of American Geographers, please do not cite without permission

were still unaware of the purpose of the trip years later raising vital questions about how these research groups included and informed local communities and the role that locals played in delivering access, knowledge, and nature.

Follow-up studies conducted by Robinson (2014) on ICBG Phase II and III with local ICBG participants showed that even those with a very positive view of some of the benefit-sharing compensation projects still yearned to be much more involved in the scientific aspects in any meaningful way possible. They wanted to learn more about the scientific results and have the results fed back in a way that would improve their livelihoods. As shown by Robinson:

The community seemed generally aware that some research had occurred but did not seem concerned-perhaps, because of the predominant focus of soil and marine microbes. Members of most villages noted that they did not know anything about the results of the research ... $(2014,60)$.

Another echoed:

We have heard the results of marine and terrestrial research [by MBG and CI] but it is not enough. We are hopeful that we could hear more results. We have questions of access to information from researchers. We'd like to know more-for example, we don’t know why the marine bioprospecting was important.

A group of respondents in the town of Ibity responded:

In this group of interviewees, one man had been involved as a guide during bioprospecting activities. The MBG officer at the site, Mamisoa, had been involved in the collection of soil (bioprospecting) and plant identification activities (for herbarium vouchering only) at this site (and in Zahamena and Diana). He noted that there was no training really for local people_-some of them just received some basic pay for their 
Accepted manuscript for the Annals of American Geographers, please do not cite without permission

work as guides or porters ... However, the training of Malagasy people who work for MBG was highlighted by a number of interviewees (Robinson 2014, 69-70).

The gaps in scientific knowledge that rural residents had are significant. The benefits that rural residents think potentially can be returned will add to their "buy-in" to the project's goals. If they see the project as a "one-time only” employment opportunity with no prospect for future returns, there is little chance of long-term biodiversity conservation. At this point, when collection from a given rural area is over, unless re-collection is ordered, many in the team will never return to the area. With little scientific sharing or participation in return, the irony is not lost on some Malagasy:

They collect medicinal plants. Some of the plants couldn’t be found in their area so they come here because we can get drugs from our plants. They have lots of benefits because they make the drugs in their country ... they'll keep it [the drugs] but we will be the one who buy it later.

In fact, contrary to the misconception that the bioprospecting mission is complete, in reality as the material heads to the drug discovery laboratories, the search for a usable drug from the material collected has only just begun. In this light, the longer-term microprojects are understood as payment to the commune for access to its forests. Would people’s feelings change if they understood the massive profits that might be had from the discovery of a drug? Very few rural residents seemed to understand that their plants might be valuable, yet if they understood more, would they be more willing to work with researchers or more resistant? Much remains to be seen, but as it stands now, it appears ICBG is only keen on telling people on a "need-to-know" basis and providing little return for their labor in either a fair wage or real participation in the scientific process. $^{23}$ 
Accepted manuscript for the Annals of American Geographers, please do not cite without permission

\section{Discussion and Conclusion}

This article makes a distinctive theoretical and empirical contribution to a human rights debate between scientific knowledge and its co-production by a precarious labor force. While these two issues, labor rights and benefits from science, are dealt with separately, the work highlights the potential of fusing the two approaches. Empirically, we provide unique perspectives from local inhabitants and laborers in order to demonstrate our critiques of how the collaborative scientific partnerships of the ICBG promote uneven sharing of the benefits and burdens of drug discovery.

The issues are informed by scholars engaged in key concerns of human rights, equity, and the ability to participate in science (Chapman 2009; Chapman and Wyndham 2013; Morgera 2015). We have put forward a new way of thinking about the benefits to science and labor that arise within bioprospecting, market conservation, and beyond (green and carbon economies). Our first concern is the recognition of the rights of local participants to fully engage in the scientific practice. But how citizens are meant to participate in the bioprospecting and how they really end up participating are two very different things. Rather than full participation, results show that Malagasy are continually "bought off" through sometimes meager benefit-sharing. This represents a subtle, but significant, form of marginalization where rural Malagasy take on facilitation of bioprospecting activities without knowledge of the project's mission to discover drugs or benefits they could receive ("real" compensation), and/or the potential or actual burdens of their participation. This builds on the claim by Schroeder et al. (2008, 550 see also Walker 2012) that benefits and burdens in sustainable development are not universally accepted or understood, but rather their conceptualization is "always relative, both in absolute terms and with respect to any particular group of potential resource users.” 
Accepted manuscript for the Annals of American Geographers, please do not cite without permission

Second, in locations where resources are collected, Malagasy hold very little knowledge about the projects and what type of benefits, if any; they may receive from the discovery of a drug. This ignorance may develop because of a history of indirect attempts by bioprospectors to hold back vital information about their goals of drug discovery so that rural actors will, first, not restrict access to collection sites if they feel they are not being fairly compensated, and second, continue to participate as manual laborers (Hayden 2003; Neimark 2012). This links with Keller's (2015) very similar accounts about the lack of knowledge and utter confusion surrounding conservation projects’ mission, governance, and the potential and actual effects on locals’ already precarious livelihoods.

For instance, although there has been some reserved optimism from rural Malagasy about the protection of local resources affiliated with related conservation activities, there still seems to be confusion as to just what "protection” means in this context (Robinson 2014; Miller 2015). In some cases, residents question their ability to restrict access to any foreigners (scientists or business people) coming to collect mineral or bioprospecting resources. Many of these access dynamics are meant to be addressed by companies, conservation NGOs, and the scientific research community. This responsibility has been particularly important since the "roll back" of the state in rural development and the increasing part that both NGOs and the private sector now play in market conservation and sustainable rural development. This is central to Ferguson’s identification of development agencies in Lesotho as an ““anti-politics machine,' de-politicizing everything it touches, everywhere whisking political realities out of sight, all the while performing, almost unnoticed, its own pre-eminently political operation of expanding bureaucratic state power” and now non-state power $(1994, \mathrm{xv})$. One of the key outcomes from this work is to illustrate how scientific institutions and other conservation NGOs can begin to take on responsibilities to ensure that a range of rights, from the benefits to science to associated development services, are respected and delivered. 
Accepted manuscript for the Annals of American Geographers, please do not cite without permission

This follows similar market-based interventions both in bioeconomy and emerging green economy (from Ecotourism to Payments for Ecosystem Services, REDD+, and biodiversityoffsetting mining schemes), which are measured in short-term monetary benefits, but fail to account for the costs (social capital, added labor, loss of access to resources) of the interventions. Recent studies in Madagascar shows the role of a scientific labor force (both skilled and manual labor) and their involvement in the bio- and green economy, including work by zoologists and biologists in the creation of protected areas for ecotourism (Sodikoff 2012; Keller 2015), botanists inventorying species for biodiversity offsetting (Neimark and Wilson 2015), and gemologists speculating and creating value in gemstone mining (Walsh 2012). This is not a phenomenon only observed in Madagascar, but represents a global trend demonstrating the central role that scientific labor plays in auditing, verifying, and inventorying nature for purposes of value creation in market conservation and beyond. This is particularly poignant as newly commodified forms of nature envisaged in the bio- and green economy are increasingly becoming less material and more financialized (e.g. carbon credits, ecosystem services). This trend highlights the vital role researchers play in articulating the scientific metrics used to standardize and legitimize nature's monetary worth for market conservation (Robertson 2006; McAfee and Shapiro 2010; Neimark and Wilson 2015).

In the case of ICBG, there is not yet a commercial product, and benefits are outlined within a pre-determined bioprospecting contract signed by all organizations and institutions involved. In this context, "upfront” benefits are distributed first on the basis of involvement in particular projects, groups, or organizations, and second on the basis of professional expertise. It has been shown elsewhere that some Malagasy research scientists are able to tap into scientific benefits in the form of technology (equipment and materials) and knowledge (plant databases, training) now available to them through their participation in the project (Neimark 2012; Robinson 2014; Miller 2015). While this definitely points to a more positive 
Accepted manuscript for the Annals of American Geographers, please do not cite without permission

direction for some living close to collection areas, in the end, scientific research organizations and environmental NGOs must find better ways to inform rural inhabitants about the project's goals and possible expanded scientific benefits of their activities. They must also devise ways to enable these groups to participate not just in the decision-making process, but in some meaningful way in the science, such as by direct training in drug discovery or other forms of benefit access (e.g., health care).

Moving forward, it is clear that from the HRS perspective that bioprospecting has not respected the provisions of Article 27 of the UDHR and Article 15 in the ICESCR. From the quotes and the observations in the field we got a real sense that not "everyone has the right to share in the scientific advancements and its benefits" (Article 27[1]), and the "rights [are not] recognized of everyone to enjoy the benefits of the scientific progress and its application” (Article 15[1b]) in the narrow sense. Bioprospecting contracts, even those negotiated under the auspices of the CBD, remain elusive, and as this case study has so visibly demonstrated, fair and equitable sharing of the benefits remains an ambitious but unclear goal under international law. Therefore, it is important that precarious workers in conservation and bioprospecting contracts look for alternative strategies to protect their basic human rights under the banner of the HRS. A broader interpretation of the meaning of the HRS closely linked to other human rights obligations, such as the right to work, might lead to more tangible outcomes for low-skilled Malagasy workers. This would particularly be the case if we linked the right to work to some of the work that the ILO is undertaking to protect the position of precarious workers. For example, in 1999, the ILO initiated a platform of "Decent Work”, which was a first step in responding to "globalization.” Yet the program has not really responded to the need to "improve the conditions of all people, waged and unwaged, working in the formal and informal economy, through efforts at re-regulation and the expansion of social and labor protections” (ILO 1999, 3-4; Vosko, 2002, 26). It is important 
Accepted manuscript for the Annals of American Geographers, please do not cite without permission

though that we also highlight that it is not only workers recruited under bioprospecting contracts or biodiversity initiatives who can fall back on these provisions under the ILO and the UDHR, but that researchers from universities, and conservation and other research organizations, can be held accountable for not fulfilling their obligations to respect everyone’s human rights. Hopefully, arrangements such as the HRS can help deliver a new framework which holds host governments and others (NGOs and companies) accountable in delivering direct scientific rights and benefits, including a decent wage for precarious workers.

\section{Acknowledgments}

The authors would like to thank the participants of the Benelex workshop 'Human Rights to Science' hosted by Elisa Morgera at the University of Edinburgh in May 2016 for their insightful comments. A special thanks to Gordon Walker, James McCarthy, and Laura Tilghman and three anonymous reviewers from the Annals of the American Association of Geographers for their suggestions on earlier versions of the article. We would like to acknowledge CNARP for logistical support while in Madagascar. Fieldwork research for this article was funded by Fulbright Institute for International Education (IIE) research award. 
Accepted manuscript for the Annals of American Geographers, please do not cite without permission

\section{Notes}

1. The ICBG (2003-2013) was a private/public consortium of research organizations MBG and CNARP, Conservation International (CI), and commercial partners (Dow AgroSciences and EISAI Pharmaceuticals).

2. Field research was conducted by the first author and draws on qualitative methods including over 78 semi-structured interviews with rural inhabitants, research scientists, and policy administrators involved in bioprospecting. Participant observation was also done on two bioprospecting expeditions $(2005,2007)$ in the Antsiranana region of Madagascar. This empirical work was updated with recently published ICBG project/academic literature and interviews with ICBG bioprospectors in Madagascar in 2014. All names of research participants are pseudonyms; Malagasy village names have also been changed.

3. In $2006,5,000 \mathrm{MGA} \approx$ U.S. $\$ 2.50$

4. Rabesandratana 2013.

5. The UDHR (1948) is the centre piece of international human rights and is the first international instrument protecting the basic rights of the individual. ICESCR (1966, ratified 1976) is one of three international covenants subsequently designed to transform the UNDR into binding treaty obligations.

6. Examining ICBG Phase I, anthropologist Laura Tilghman noted that porters often guide collectors indirectly towards medicinally useful plants and a way from alreadycollected duplicate samples; and that bioprospectors rate duplicate collecting as one of the most expensive aspects of the scientific discovery process (personal 
Accepted manuscript for the Annals of American Geographers, please do not cite without permission

communication via Skype 2016). Other similar transmission of knowledge between manual workers and scientists is very common in the bioprospecting literature (Hayden 2004).

7. This is focused within Article 8(j) of the CBD, which gives communities the right to benefit from their cultural and biological resources. These benefits are determined by an Access and Benefit Sharing agreement, and were codified in the long-awaited 2010 Nagoya protocol which so far has not addressed labor rights of precarious conservation workers.

8. For more information see http://www.aaas.org/program/science-human-rightscoalition (last accessed 30 December 2015).

9. For full description see Chapman 2009, 25.

10. The Maastricht Principles were issued on 28 September 2011 and constitute an international expert opinion, restating (rather than establishing new) human rights law on ETOs; they clarify extraterritorial obligations of states and third parties on the basis of international law.

11. Successful implementation of human rights is difficult to quantify, but numerous cases exist of their effect on protecting marginalized indigenous communities, particularly concerning access and sovereignty in relation to the environment (UNEP 2014), and land access and the right to food (De Schutter 2011).

12. The ILO has been criticized for failing to protect poor skilled workers, despite the 1999 “Decent Work” program (ILO 1999; Vosko 2002). 
Accepted manuscript for the Annals of American Geographers, please do not cite without permission

13. For example, in Siliadan v France, the court upheld that modern slavery imposes a duty to enact legislation criminalizing such conditions (Mantouvalou 2012).

14. In Madagascar, direct applicability of international conventions by the courts is guaranteed by the constitution, which, in its preamble, recognizes the International Bill of Human Rights, the African Charter on Human and Peoples’ Rights, and the conventions on the rights of women and the rights of the child.

15. This team also included representatives from MBG, CI, U.S. National Institutes of Health (NIH), National Science Foundation, and U.S. Agency for International Development (since replaced by U.S. Department of Agriculture).

16. Since Madagascar currently does not have a specific law for bioprospecting, ICBG was set up alongside the guidelines of already established access and benefit-sharing agreement between U.S. NIH and CNARP.

17. These programs have shown mixed results in demonstrating that long-term conservation goals are met through bioprospecting (Neimark 2012; Neimark and Tilghman 2015).

18. To obtain collection permits, scientists must apply through the ad hoc Flora/Fauna Committee/Orientation Committee for Environmental Research (CAFF-CORE).

19. A kabary is a cultural form of communication and political speech, whereby Malagasy indirectly explain a historical event relevant to a current situation.

20. This understanding of their resources is quite similar to Andrew Walsh's depiction of Ankarana forests as central in a "global bazaar" where foreign eco-tourists, gemstone 
Accepted manuscript for the Annals of American Geographers, please do not cite without permission

miners, and bioprospectors all supply a worldwide demand for Madagascar’s “natural wonders" $(2015,74)$.

21. Also quoted in Neimark and Schroeder 2009.

22. Many of these "benefits” are listed in detail within the different sites (see Robertson 2015). Return visits to Phase I sites have shown that many of these conservationbased projects fall into disrepair once the project leaves (Laura Tilghman, personal communication via Skype 2016).

23. Other recent studies, some by members of ICBG-Madagascar themselves, note that delivery of new equipment and the many training sessions held within Malagasy research institutions directly target Malagasy scientists (Miller 2015; Missouri Botanical Garden 2016). While this form of “technology transfer” is an accomplishment in terms of benefit-sharing delivery, it falls short of addressing scientific capacity building or participation at the local level. 
Accepted manuscript for the Annals of American Geographers, please do not cite without permission

\section{References}

Anderson, D., and R. Grove, ed. 1987. Conservation in Africa: People, policies and practices. New York: Cambridge University Press.

Bebbington, A., S. Hickey, and D. Mitlin, ed. 2008. Can NGOs make a difference?: The challenge of development alternatives: London: Zed books.

Bernards, N. 2015. The internationalization of labor politics in Africa. Critical African Studies 7 (1): 7-25.

Brockington, D., and R. Duffy. 2010. Capitalism and conservation: The production and reproduction of biodiversity conservation. Antipode 42 (3): 469-84.

Büscher, B., S. Sullivan, K. Neves, J. Igoe, and D. Brockington. 2012. Towards a synthesized critique of neoliberal biodiversity conservation. Capitalism Nature Socialism 23 (2): $4-30$.

Buss, D., and A. Manji, ed. 2005. International law: Modern feminist approaches. Oxford: Hart Publishing.

Cavanagh, C., and T. A. Benjaminsen. 2014. Virtual nature, violent accumulation: The "spectacular failure” of carbon offsetting at a Ugandan national park. Geoforum 56: $55-65$.

Chapman, A., and J. Wyndham. 2013. A human right to science. Science 340 (6138): 1291.

Chapman, A. R. 2009. Towards an understanding of the right to enjoy the benefits of scientific progress and its applications. Journal of Human Rights 8 (1): 1-36.

Danielsen, F., N. D. Burgess, and A. Balmford 2005. Monitoring matters: Examining the 
Accepted manuscript for the Annals of American Geographers, please do not cite without permission potential of locally-based approaches. Biodiversity \& Conservation 14 (11): 2507-42.

De Schutter, O. 2011. The right of everyone to enjoy the benefits of scientific progress and the right to food: from conflict to complementarity. Human Rights Quarterly 33: 30450.

De Schutter, O., A. Eide, A. Khalfan, M. Orellana, M. Salomon, and I. Seiderman. 2012. Commentary to the Maastricht Principles on extraterritorial obligations of states in the area of economic, social and cultural rights. Human Rights Quarterly 34 (4): 1084169.

Donnelly, J. 2003. Universal human rights in theory and practice. Ithaca, NY: Cornell University Press.

EC, 2009. The bioeconomy strategy. http://ec.europa.eu/research/bioeconomy/policy/bioeconomy_en.htm (last accessed 10 April 2016).

Fairhead, J., M. Leach, and I. Scones. 2012. Green Grabbing: a new appropriation of nature? Journal of Peasant Studies 39 (2): 237-61.

Ferguson, J. 1994. The anti-politics machine: Development, depoliticization, and bureaucratic power in Lesotho. Minneapolis, MN: University of Minnesota Press.

Fletcher, R. 2010. Neoliberal environmentality: Towards a poststructuralist political ecology of the conservation debate. Conservation and Society 8 (3): 171-81.

Gross, J. A. 2003. A long overdue beginning: The promotion and protection of workers' rights as human rights. In Workers’ rights as human rights, ed. J. A. Gross. 1-22. Ithaca, NY: ILR Press. 
Accepted manuscript for the Annals of American Geographers, please do not cite without permission

Hayden, C., 2003. When nature goes public: The making and unmaking of bioprospecting in Mexico. Princeton, NJ: Princeton University Press.

Hickey, S., and D. Mitlin. 2009. Rights-based approaches to development: Exploring the potential and pitfalls. Sterling, VA: Kumarian Press.

Hiskes, R. 2005. The right to a green future: human rights, environmentalism and intergenerational justice. Human Rights Quarterly 27: 1346-64.

Ignatieff, M. 2001. Human rights as politics and idolatry. Princeton, NJ: Princeton University Press.

ILO, 1999. Report of the director-general: Decent work. International Labor Conference, 87th Session, Geneva.

Janzen, D. 2004. Setting up tropical biodiversity for conservation through non-damaging use: participation by parataxonomists. Journal of Applied Ecology 41: 181-7.

Jasanoff, S. 2006. Biotechnology and empire. Osiris 21 (1): 273-92.

Keller. E. 2015. Beyond the lens of conservation: Malagasy and Swiss imaginations of one another. New York, Oxford: Berghahn.

Koskenniemi, M. 2005. From apology to utopia. The structure of international legal argument. Cambridge, UK: Cambridge University Press.

Kumar, V. 2014. Rethinking the convergence of human rights and labour rights in international law: Depoliticisation and excess. In Law in transition: Human rights, development and transitional justice, ed. R. Buchanan and P. Zumbansen. 127-39. Oxford: Hart Publishing. 
Accepted manuscript for the Annals of American Geographers, please do not cite without permission

Li, T. 2011. Centering labor in the land grab debate. The Journal of Peasant Studies 38 (2): 281-98.

Lowe, C., 2006. Wild profusion: Biodiversity conservation in an Indonesian archipelago. Princeton, NJ: Princeton University Press.

Mantouvalou, V. 2012. Are labour rights human rights? European Labour Law Journal 3 (2): $151-72$

Missouri Botanical Garden. 2016. Discovery in Madagascar. http://www.missouribotanicalgarden.org/plant-science/plant-science/william-l-browncenter/wlbc-programs/wlbc-discovery/discovery-in-madagascar.aspx (last accessed 12 April 2016).

McAfee, K., and E. N. Shapiro. 2010. Payments for ecosystem services in Mexico: Nature, neoliberalism, social movements, and the state. Annals of the Association of American Geographers 100 (3): 579-99.

Miller, J. S. 2015. Realized benefits from bioprospecting in the wake of the convention on biological diversity. Washington University Journal of Law and Policy 47: 51.

Morgera, E. 2015. Fair and equitable benefit-sharing at the cross-roads of the human rights to science and international biodiversity law. Laws 4: 803-31.

Neimark, B. D. 2010. Subverting regulatory protection of "natural commodities": The Prunus Africana in Madagascar. Development and Change 41 (5): 929-54.

- - . 2012. Industrializing nature, knowledge, and labor: The political economy of bioprospecting in Madagascar. Geoforum 43 (5): 980-90. 
Accepted manuscript for the Annals of American Geographers, please do not cite without permission

Neimark, B. D., and R. Schroeder. 2009. Hotspot discourse in Africa: Making space for bioprospecting in Madagascar. African Geographical Review 28: 43-70.

Neimark, B. D., and L. Tilghman. 2015. Bioprospecting a biodiversity hotspot: The political economy of natural products drug discovery for conservation goals in Madagascar. In Conservation and environmental management in Madagascar, ed. I. Scales. 271-98. London: Routledge.

Neimark, B. D., and B. Wilson. 2015. Re-mining the collections: from bioprospecting to biodiversity offsetting in Madagascar. Geoforum 66: 1-10.

Parry, B. 2004. Trading the genome. New York: Columbia University Press.

Rabesandratana, 2013. Q\&A: Farida Shaheed on the human right to science. http://www.scidev.net/global/human-rights/feature/q-a-farida-shaheed-on-the-humanright-to-science.html (last accessed 10 June 2016).

Robinson, D. F. 2014. Biodiversity, access and benefit-sharing: Global case studies. London: Routledge.

Robertson, M. 2006. The nature that capital can see: Science, state, and market in the commodification of ecosystem services. Environ. Plan. D 24 (3): 367-87.

Roth, R. J., and W. Dressler. 2012. Market-oriented conservation governance: The particularities of place. Geoforum 43 (3): 363-66.

Schroeder, R., K. S. Martin, B. Wilson, and D. Sen. 2008. Third world environmental justice. Society and Natural Resources 21 (7): 547-55.

Shaver, L. 2010. The right to science and culture. Wisconsin Law Review 1: 121-84. 
Accepted manuscript for the Annals of American Geographers, please do not cite without permission

Shiva, V. 1997. Biopiracy: The plunder of nature and knowledge. Boston, MA: South End Press.

Sodikoff, G. 2007. An exceptional strike: A micro-history of "People versus Park" in Madagascar. Journal of Political Ecology 14: 10-33.

2009. The low-wage conservationist: Biodiversity and perversity of value in Madagascar. American Anthropologist 111 (4): 443-55.

-2012. Forest and Labor in Madagascar: From Colonial Concession to Global Biosphere. Bloomington, IN: Indiana University Press.

UNEP, 2014. UNEP compendium on human rights and the environment. Selected international legal materials and cases. www.unep.org/environmentalgovernance/Portals/8/.../UNEP_Compendium_HRE.pdf (last accessed 4 March 2016.

UDHR. 2011. Guiding principles on business and human rights: Implementing the United Nations "Protect, Respect and Remedy” framework. Special Representative of the Secretary-General, New York.

Vermeylen, S., G. Martin, and R. Clift 2008. Intellectual property rights and the assemblage of local knowledge systems. International Journal of Cultural Property 15: 201-21.

Vermeylen, S., and G. Walker. 2011. Environmental justice, values and biological diversity: the San and the Hoodia benefit sharing agreement. In Environmental inequalities beyond borders: local perspectives on global injustices. 105-28. Cambridge, MA: MIT Press. 
Accepted manuscript for the Annals of American Geographers, please do not cite without permission

Vosko, L. 2002. “Decent Work” The shifting role of the ILO and the struggle for global social justice. Global Social Policy 2: 19-46.

Wainwright, J. 2012. Geopiracy: Oaxaca, militant empiricism, and geographical thought. New York: Palgrave Macmillan.

Walker, G. 2012. Environmental justice: Concepts, evidence and politics. London: Routledge.

Walsh, A. 2012. Made in Madagascar: Sapphires, ecotourism, and the global bazaar. Toronto: University of Toronto Press.

Wyndham, J. M., R. Albro, J. Ettinger, K. Smith, M. Sabatello, and M. S. Frankel. 2015. Social responsibilities: A preliminary inquiry into the perspectives of scientists, engineers and health professionals. Report prepared under the auspices of the AAAS Science and Human Rights Coalition and AAAS Scientific Responsibility, Human Rights and Law Program, March 2015.

Zerner, C. 2000. Introduction: Toward a broader vision of justice and nature conservation. In People, plants and justice: The politics of nature conservation, ed. C. Zerner. 3-20. New York: Columbia University Press. 